\title{
Lactation and gestation in dairy cows: flexibility avoids nutritional extremes
}

\author{
Christopher H. Knight \\ Hannah Research Institute, Ayr KA6 5HL, UK
}

\begin{abstract}
The modern dairy cow has been selectively bred to produce large amounts of milk. Partly as a result, food consumption is considerably less than milk energy output in early lactation. It is only at 2 months or more postpartum that intake increases to the point where positive energy balance is regained, the initial production being achieved by a substantial mobilisation of body reserves. These reserves are laid down before parturition, but it is certainly not the case that the pregnant cow will accumulate adipose tissue recklessly; in the last third of pregnancy well-fed cows in good body condition exhibit reduced, not increased, appetite. There is a fine balancing act to perform. Excessive body condition at parturition quickly leads to metabolic problems such as ketosis, but cows who subsequently become too thin have increased risk of metabolic diseases such as mastitis and lameness. The biological mechanisms regulating output of milk are reasonably well understood, those controlling appetite less well so, and there has been little attempt at systematic integration of the two. The transition from pregnancy to lactation represents a major challenge to homeostasis, made more complicated in multiparous cows by the fact that much of gestation is concurrent with lactation. Herein lies the potential for nutritionally-entrained flexibility. In the wild, concurrent pregnancy and lactation only occur when nutritional conditions are favourable. If conditions are poor, rebreeding will be delayed and lactation will continue, at an energeticallysustainable level, for much longer than its 'normal' duration. In this way the twin energetic burdens of pregnancy and lactation are separated, and extremes are avoided. Given the increasing public concern about stresses suffered by intensively-managed dairy cows, this case may be one where commercial dairying could learn useful lessons from nature.
\end{abstract}

Lactation: Energy balance: Dairy cows: Food intake: Milk yield

Strategies adopted by female mammals to meet the energetic costs of pregnancy and, particularly, lactation are many and varied, but inevitably involve one or more periods of increased food intake. It is equally inevitable that the control of intake must somehow be coordinated with the regulation of output, although the way in which this coordination is achieved is incompletely understood. Sometimes the coordination appears to fail; the early-lactation dairy cow does not take in as much energy as she puts out and is, therefore, in negative energy balance. This situation needs to be seen in the light of the overall strategy; there is another level of coordination to be achieved, between short-term dynamic regulation of energy balance and long-term control of body condition. A fundamental requirement is for the animal to be able to monitor its own energetic status, both in a dynamic sense and in terms of reserves. Leptin, an endocrine product of adipose tissue, is attracting considerable interest in this regard, and recent data pertaining to its role in lactating ruminants will be reviewed. The final part of the paper will deal with the options available to the cow. The biological objective is transfer of genes through to the next generation and beyond, so the more calves successfully reared to maturity the better. The emphasis has to be on successfully reared; rebreeding is pointless until the mother is ready to support that new investment and the first calf is ready to support itself. This factor means that lactation length is bound to be plastic, something hitherto largely unexploited by dairy farmers. 


\section{Extremes of metabolism}

Output of milk

Following calving milk yield increases to reach a peak at about 8 weeks postpartum and then gradually declines, at a rate of about $2 \% /$ week, such that the lactation will normally last for about 10 months. Usually the cow will have been concurrently pregnant during most of this declining phase. The intensive lactation cycle typical of most milk production in the UK and elsewhere is based around the twin tenets of maximising peak milk yield and minimising calving interval. In the UK 'good' cows yield in excess of $30 \mathrm{~kg} / \mathrm{d}$ at peak lactation whilst the best exceed $40 \mathrm{~kg} / \mathrm{d}$, both are expected to re-calve within $365 \mathrm{~d}$ or thereabouts, which means rebreeding at about peak lactation (Esslemont \& Kossaibati, 2000). For evaluation purposes, commercial milk production is usually reported as $305 \mathrm{~d}$ lactation yields, calculated from monthly yield recording. On this basis the top UK herds aim for $10000 \mathrm{~kg}$ per cow, whereas the national average is about $6500 \mathrm{~kg}$ per cow. As an illustration of the extreme case, a recent Symposium of the American Dairy Science Association (Anon, 2000) dealt with Management of dairy herds for 40000 pounds of milk per year. The conversion from US pounds to kilogrammes is 0.454 , so this objective equates to $18000 \mathrm{~kg}$, approaching three times the UK average! For the purposes of the present review daily output is more relevant than lactation yield. One of the best scientifically documented examples of extreme output of which I am aware is a study of Israeli Holsteins, a particular group of which achieved a peak yield of $60 \cdot 0$ (SE 2.9) kg/d (Bar-Peled et al. 1995).

\section{Food intake}

Food intake by dairy cows has been intensively researched; a recent review by Ingvartsen \& Andersen (2000) cited about 344 references. Much of this effort has been directed to the construction of predictive models of intake which then enable the farmer to maximise feeding efficiency during lactation (for example, see Roseler et al. 1997), so most research deals with the lactating cow. Broster (1971), 30 years ago, stressed the importance of prepartum feeding, something which has recently been rediscovered and dubbed the 'transition period' (typically defined as the last 3 weeks of pregnancy and the first 3 weeks of lactation). Indeed, Drackley (1999) was moved to label this 'the final frontier' of lactation biology! Whilst Broster's (1971) observations were a step in the right direction, by concentrating on late pregnancy they still missed possibly the most fundamental teological point of lactation. The success of mammals is largely ascribable to the fact that, by drawing on body reserves to synthesise milk, the mother can rear young under conditions which would not directly support the nutritional requirements of those young (Pond, 1984). Part of the preparation for lactation, therefore, is the creation of these body reserves. When does this occur? Not in late pregnancy; the energetic demands of the growing fetus and mammary gland are greatest, by far, at this time (Bauman \& Currie, 1980), so it would be folly for the mother to leave such a vital process until then. Rather, one would anticipate that as soon as there is a commitment to lactation (i.e. soon after conception or implantation) the storage process would commence. In support of this possibility, evidence of deposition of adipose reserves from early in gestation does exist in a variety of species, including sheep (Vernon et al. 1981). In the cow, however, whilst there is clear evidence of adipose mobilisation during early lactation, it is an unproven assumption that accretion occurs during pregnancy. Although deposition of adipose does not necessarily require increased food intake (Robinson, 1986), the endocrine environment of early pregnancy (low oestrogens, high progesterone) is stimulatory to appetite and the phenomenon of increased intake has been recognised for some time, at least in rats (Morrison, 1956). If the following quote from Johnson et al. (1966) is to be believed, the same is not true of cattle: '...suggestions of increased appetite accompanying pregnancy in dairy cattle are entirely unfounded'. The statement was based on food intake data obtained from mature cattle that were lactating as well as pregnant, and so may not be accurate, but the real surprise is the paucity of data on the subject. I am aware of only one study which has followed food intake of growing heifers from before conception through the whole of pregnancy (Ingvartsen et al. 1992). Analysis was done by body weight rather than by stage of pregnancy and, since the purpose was to construct a mathematical model of food intake, the only data reported are calculated intakes rather than actual intakes. However, it is recorded that the predicted intake of heifers mated at the first oestrous after $325 \mathrm{~kg}$ did not deviate from actual intake at body weights of 375 and $425 \mathrm{~kg}$, nor was it any different from the intake of steers (castrated males) of the same body weight. The somewhat tentative conclusion must be that food intake did not increase during the early stages of gestation.

More recently, Ingvartsen (Ingvartsen et al. 1999; Ingvartsen \& Andersen, 2000) has presented food intake data for heifers from week 17 of pregnancy onwards. The initial intake value of about $8 \mathrm{~kg} \mathrm{DM} / \mathrm{d}$ was similar to that previously reported for non-pregnant heifers, but by week 23 intake had risen approximately $50 \%$ to $12 \mathrm{~kg} \mathrm{DM} / \mathrm{d}$, considerably in excess of what would be expected (on the basis of the earlier model) had they not been pregnant. This apparent evidence of increased intake to facilitate the creation of body reserves was not analysed statistically or commented on in either of the reviews. From week 26 onwards, intake fell gradually to reach a nadir at parturition. The extent to which intake decreases in late pregnancy is related to energy status; the greater the energy content of the diet, the less is eaten (Coppock et al. 1972). Presumably the cow moves towards a target body condition state at parturition; in other words, the creation of body reserves is a regulated process. Given that body reserves are so crucial to the subsequent lactation, it is somewhat curious that research has been directed at the later, adjustment, stage of this process, whilst ignoring the earlier, storage, phase.

There is a marked nadir in food intake around calving, followed by a gradual increase to a value about twice that of the non-pregnant heifer $(16 \mathrm{~kg} \mathrm{DM} / \mathrm{d})$. This increase is quite variable between cows, but in the great majority of cases does not keep pace with milk yield. Whereas output peaks at about 2 months, intake may take at least twice as long to 
reach its maximum. This lag of energy intake behind energy output was recognized some time ago (Bauman \& Currie, 1980), but is arguably more relevant today, since yields have increased markedly in the last few decades. The net result is that high-yielding dairy cows are almost certain to be in negative energy balance for the first 2 months of lactation, and are likely to be so for about the first 4 months; in one recent study positive balance was still not restored after 20 weeks (Beever et al. 1998). This situation occurred despite the cows being fed a high-quality diet on which some individuals achieved an intake of $>28 \mathrm{~kg} \mathrm{DM} / \mathrm{d}$.

In a gross sense, intake across the whole of a lactation correlates reasonably well with output; high-genetic-merit cows eat more than low-merit cows (Veerkamp et al. 1995), and multiparous cows eat more than heifers (Ingvartsen \& Andersen, 2000). It would be a surprise if this situation was not so; dairy cows adhere to simple energetic laws, after all. If one focuses on particular periods, specific diets or compares different breeds, however, the relationship often breaks down because of variation in the way ingested nutrients are partitioned between mammary and storage tissues. Thus, high-merit cows on poor-quality diets will still yield more milk than low-merit cows, but they will do it by mobilising to a greater extent, rather than by eating more (Veerkamp et al. 1995).

The lactating heifer which then becomes pregnant will maintain its maximum intake at about $16 \mathrm{~kg} \mathrm{DM} / \mathrm{d}$ until about the last third of the concurrent pregnancy, thereafter intake will start to decline (Ingvartsen \& Andersen, 2000). Milk yield, meanwhile, will have been declining for some considerable time. Thus, for much of the declining phase of lactation, intake runs ahead of output, as depleted body reserves are restored in readiness for the next lactation. Intake decreases further after drying-off; nevertheless, the amount consumed remains well above what was eaten at the same stage of the first pregnancy, in line with the increase in body weight. Similarly, food intake during the first few weeks of the second and subsequent lactations is higher than that of the heifer lactation (Ingvartsen \& Andersen, 2000).

\section{Mobilisation in early lactation}

The metabolic impact of lactogenesis was neatly summarised by Bell (1995): 'The onset of lactation in the high yielding dairy cow imposes dramatic increases in requirements for glucose, amino acids and fatty acids that cannot be met by dietary intake.' It should be remembered that the pregnant cow is already investing considerable resources into the fetus; nevertheless, the postpartum mammary requirements for these precursors were estimated to be respectively $2.7,2.0$ and 4.5 times those of the growing conceptus (Bell, 1995). Furthermore, these values were calculated at $4 \mathrm{~d}$ into lactation, long before the peak output of milk, and at a time when food intake had hardly increased above its late-pregnant value. To complete the equation, Bell (1995) calculated the increment in dietary supply of glucose to be approximately half that actually required to support milk production, and showed that these early-lactation cows were in negative energy balance to the extent of $-50 \cdot 2 \mathrm{MJ}(-12 \mathrm{Mcal} / \mathrm{d})$. This level of deficit is not an extreme; in a more recent study by the same group cows milked three times daily in the immediate postpartum period had a deficit of $-84 \mathrm{MJ}(-20 \mathrm{Mcal}) / \mathrm{d}$ (Block et al. 2000). Reflecting the high mammary requirement, plasma glucose was $330 \mathrm{mg} / \mathrm{l}$ compared with $590 \mathrm{mg} / \mathrm{l}$ in 'control' cows which went through a normal pregnancy but were dried-off immediately postpartum. On the other hand, nonesterified fatty acids (products of adipose mobilisation) were four times higher in the lactating cows $(882 \mu \mathrm{mol} / 1 v$. $218 \mu \mathrm{mol} / \mathrm{l})$. The most extreme examples of tissue mobilisation to support lactation are presumed to occur in species such as fur seals, bears and baleen whales, which lactate whilst fasting (Oftedal, 2000). The composition of the milk of these species (low-sugar high-fat) is designed to minimise requirements for gluconeogenesis, whilst maintaining the supply of energy to the young. Nevertheless, it remains a fact that the entire energetic and substrate costs of the milk production must be met from body reserves. Calculations suggest that such animals can lose as much as one-third of their body fat and one-fifth of their body protein (Oftedal, 2000). Only a very few studies have quantified the actual loss of body tissues by dairy cows using slaughter and carcase analysis, and those studies have suffered from inadequate replication. Thus, Gibb et al. (1992) reported losses of fat that barely achieved statistical significance, yet amounted to one-third of the available body fat, in cows which were average rather than high yielders. By contrast, their estimate of tissue protein mobilisation was about $100 \mathrm{~g} / \mathrm{d}$, giving an overall depletion of $6.6 \%$ of the total body protein, whereas Bell et al. (2000) have suggested a daily requirement ten times this amount! Reasons for the discrepancy probably relate to the intervals studied; the $100 \mathrm{~g} / \mathrm{d}$ estimate is for the whole of the period up to peak lactation, whereas the $1 \mathrm{~kg} / \mathrm{d}$ estimate is for about the first week. Whilst mobilisation of fat may continue for several months, increased intake of highprotein diets means that metabolizable protein balance will be restored after about 3 weeks, even in high-yielding cows (Bell et al. 2000).

Clearly, the dairy cow has the capacity to mobilise considerable amounts of adipose tissue over fairly protracted periods and substantial quantities of protein, the latter only over short periods. For the most part this mobilisation will occur during early lactation, although it is worth remembering that the requirements of the thirdtrimester fetus are considerable and, in sheep at least, there is good evidence of mobilisation occurring for a considerable time prepartum (Robinson, 1986). It should also be borne in mind that mobilisation is but one aspect of a repertoire of metabolic adaptations affecting many tissues in support of lactation (Bauman \& Currie, 1980; Vernon \& Pond, 1997).

\section{A specific example of an energetic extreme}

A good example of carefully documented extreme input and output is to be found in an experiment conducted in an Israeli Kibbutz, under commercial farm conditions, where management levels were good, feed quality was high and the cows had been bred to produce high yields (Bar-Peled et al. 1995). The data are summarised in Fig. 1. Three 

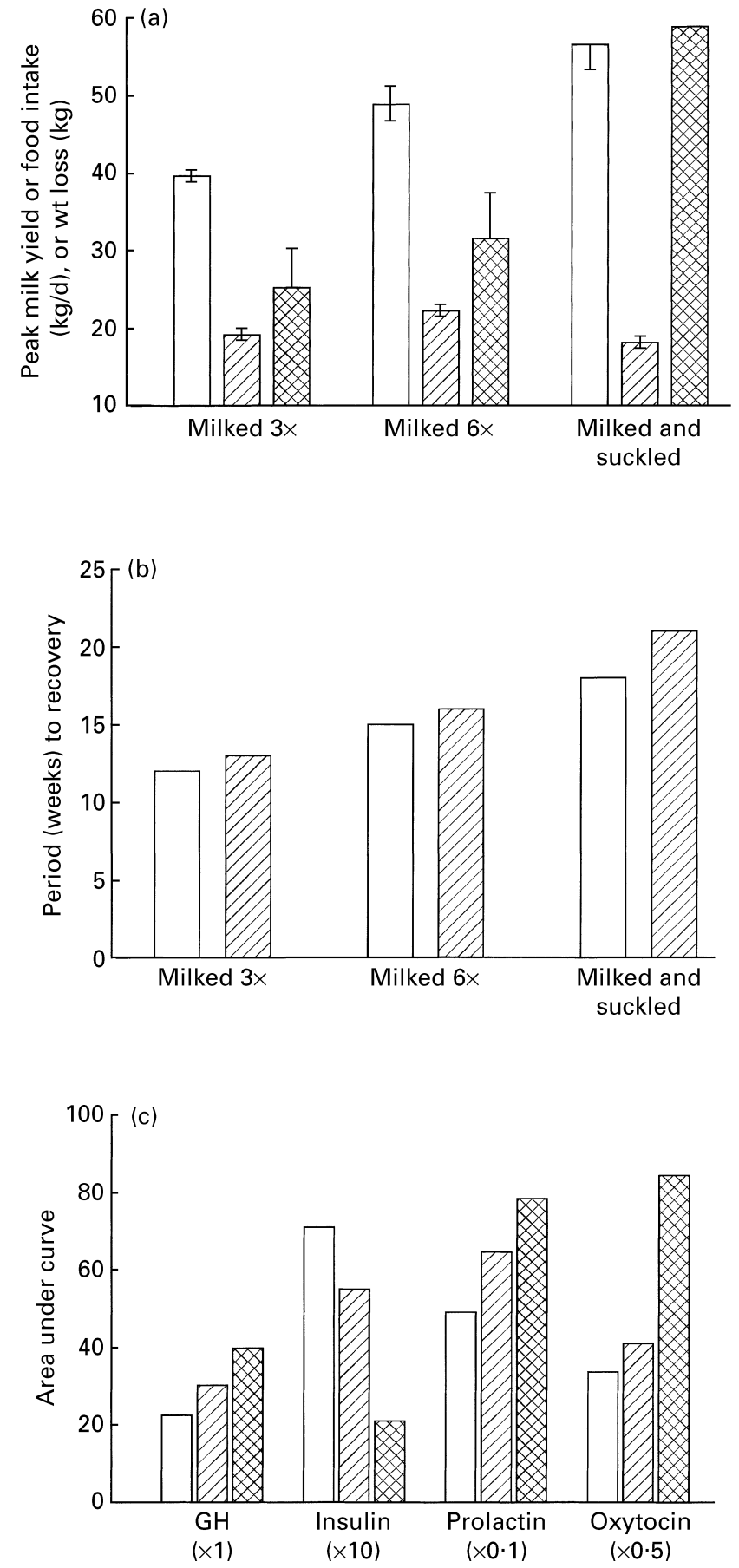

Fig. 1. Production and intake responses, tissue mobilisation and endocrine characteristics of high-yielding dairy cows milked three times daily $(3 \times)$, six times daily $(6 \times)$ or milked three times and suckled three times in early lactation. (a), Peak milk yield $(\square)$, food intake averaged over the first 6 weeks of lactation (mis) and body weight loss during the first 6 weeks of lactation $\left(\mathrm{x}_{\mathrm{x}}\right)$. Values are means with their standard errors represented by vertical bars for nine cows per treatment group. (b), The number of weeks taken to recover body weight $(\square)$ and body condition score (खाI). (c), Area-under-curve values (arbitrary units) for hormone profiles in samples taken at $30 \mathrm{~min}$ intervals for $7 \mathrm{~h}$ during

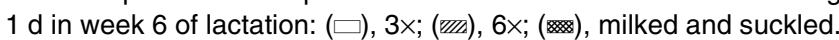
Data are adjusted as shown to fit a common ordinate. GH, growth hormone. For $\mathrm{b}$ and $\mathrm{c}$, values are means for nine cows per treatment group. (Data from Bar-Peled et al. 1995, 1998.) groups of cows were milked either three times daily, six times daily or milked three times and suckled three times daily for the first 6 weeks of lactation. In the latter group total milk yield was estimated using the weigh-suckleweigh technique to determine the intake of the two calves on $1 \mathrm{~d}$ of each week. Peak milk yields for the three groups were 40,49 and $57 \mathrm{~kg} / \mathrm{d}$ whilst DM intakes were 19, 22 and $18 \mathrm{~kg} / \mathrm{d}$ respectively (Fig. 1(a)). The frequently-milked cows increased their intake significantly (by $16 \% ; P<0.05$ ), but this increase was insufficient to account for the increased yield (of $23 \%$ ), so tissue mobilisation was greater. This mobilisation was evident as a slightly greater body weight loss (Fig. 1(a)) and a marked decrease in body condition score. Most surprisingly, the suckled cows did not increase their intake at all despite giving the highest milk yield. Their loss of body weight was over twice that of the control group and, at an average of almost $10 \mathrm{~kg} /$ week for the 6 weeks of the experiment, represented more than one-tenth of their starting weight. From week 7 of lactation onwards all the cows were milked three times daily. Another way of analysing the extent of tissue mobilisation is to measure the time taken for the original body weight and condition score to be restored; the longer this period, the greater the mobilisation. Fig. 1(b) clearly shows that mobilisation was greatest in the suckled cows and least in the controls. Further support for this finding was seen in plasma metabolite concentrations; glucose was highest in controls and lowest in suckled cows, whereas non-esterified fatty acids was highest in suckled and lowest in controls (Bar-Peled et al. 1998).

\section{Problems created by metabolic extremes}

Recently, the Farm Animal Welfare Council (1997) produced the Report on the Welfare of Dairy Cattle, and concluded: 'High metabolic turnover in cows can be associated with a greater risk of mastitis, lameness, infertility and other production diseases'. Dairy-cow fertility has decreased steadily as milk yield has increased (Webb et al. 1999). While this factor may be a serious economic concern, infertility induced by high metabolic turnover is a predictable physiological response rather than a pathological failing (Knight et al. 1999). Mastitis and lameness, on the other hand, are painful and debilitating diseases which can affect as many as one-third to half all cows (Kossaibati \& Esslemont, 2000). There can be no doubt that disease is more prevalent in higher-producing cows. Relationships with genetic merit suggest this conclusion without being totally decisive (Pryce et al. 1997), but an association between disease incidence and peak lactation is incontrovertible, having been observed in a variety of production systems (Erb et al. 1984; Grohn et al. 1986). About $60 \%$ of health costs are incurred in the first $45 \mathrm{~d}$ of lactation. Some of this cost is due to diseases specifically associated with parturition, such as milk fever, ketosis, retained fetal membranes and metritis (Drackley, 1999), but these diseases occur relatively infrequently (singlefigure incidences). Output-associated mastitis and lameness constitute a much bigger problem. The high risk period for diseases includes parturition, but extends through to peak lactation; in other words, exactly the time 
of the metabolic imbalance caused by the lag of intake behind output.

\section{Control of intake and output}

\section{Endocrine factors}

There are numerous reviews of the endocrine control of bovine lactation (Flint \& Knight, 1997; Tucker, 2000) and of food intake in dairy cows (Ingvartsen et al. 1999; Ingvartsen \& Andersen, 2000), as well as more general reviews of food intake regulation at systemic (Bray, 2000) and hypothalamic levels (Williams et al. 2000). Rather than attempt another comprehensive account, this section will highlight some of the principal endocrine factors involved in the control of milk yield, and will attempt to integrate their mammary role with any influence on food intake. The hormone data used will be those obtained in the Kibbutz experiment previously described (Bar-Peled et al. 1995), as shown in Fig. 1(c). The data are area-under-curve values for daily profiles, with adjustment to fit a common ordinate. Remembering that milk yield was lowest in controls and highest in suckled cows, positive relationships between milk yield and hormone concentration were evident for growth hormone $(\mathrm{GH})$, prolactin and oxytocin, whilst insulin was negatively correlated (Bar-Peled et al. 1998). Food intake was increased in the frequently-milked cows but not in the suckled cows, a conundrum which will be explored below, since it is not immediately explained by the endocrine changes.

The positive relationship between yield and $\mathrm{GH}$ is to be expected. $\mathrm{GH}$ is the principal galactopoietic hormone in dairy cattle (Bauman et al. 1985), recombinant GH being marketed in several countries, including the USA, for use by dairy farmers to boost milk yield (Bauman et al. 1999). It is uncertain whether GH has a direct action on bovine mammary tissue; attempts to demonstrate specific binding of GH have consistently failed (Akers, 1985), although a recent immunocytochemical study has shown the receptor to be present on the membrane and in the cytoplasm of the secretory epithelial cell (Sinowatz et al. 2000). Indirect effects mediated through endocrine or paracrine insulinlike growth factor (IGF)-1 have been postulated to account for the mammogenic and galactopoietic roles of GH (Flint \& Knight, 1997). However, its principal action is one of homeorhesis, repartitioning nutrients away from body stores and towards the mammary gland (Bauman, 1992). Injections of GH can increase food intake (Bray, 2000), and whilst there is no evidence of a direct cause and effect, cows treated with recombinant $\mathrm{GH}$ do show intake responses. Initially, mobilisation is increased, which can have the effect of reducing intake (Bareille \& Faverdin, 1996), although in practice this effect is rarely seen. After a few weeks of recombinant GH treatment voluntary food intake increases (Chalupa \& Galligan, 1989). This response is consistent and persists for as long as the treatment is continued (Bauman, 1992). Whilst it could be directly related to the increased output, the more likely explanation is that it is a response to the diminishing body reserves caused by the mobilisation. The lack of an intake response in the suckled-milked Kibbutz cows demonstrates that, whatever mechanism is involved, it can be overridden.

The metabolic adaptations of adipose tissue to lactation (increased lipolysis, decreased lipogenesis) are primarily regulated by insulin (Vernon \& Pond, 1997), as are the glucose-sparing adaptations which ensure that as much glucose as possible is channelled to lactose production (Bell, 1995). Thus, insulin insensitivity develops in peripheral tissues (adipose, muscle) during late pregnancy and continues during lactation and, in addition, insulin secretion decreases. There is no direct effect of insulin on milk secretion. Food intake, on the other hand, is insulinresponsive, in as much as insulin infusion will depress appetite (Anil \& Forbes, 1980). Insulin receptors are present in areas of the brain involved in appetite regulation, and in rats intracerebroventricular injection of insulin or insulin antibodies lowers or increases intake respectively (for review, see Ingvartsen et al. 1999). Given that insulin tends to correlate with relative extent of fatness, it has in the past been suggested as a candidate indicator of peripheral metabolic status (Williams et al. 2000). However, there is no direct evidence to suggest that insulin is involved in either the peripartum depression or subsequent increase in food intake of the dairy cow, and the differences in insulin cannot explain the anomalous food intake values of the suckledmilked cows in the Kibbutz experiment.

Prolactin release is stimulated by milking and basal levels are higher in lactating cows than in non-lactating cows when other factors such as time of year are taken into account (Koprowski \& Tucker, 1973). However, the close relationship between yield and prolactin concentration seen in the Kibbutz data is not typical; for instance, we have compared high- and low-genetic-merit cows and found no difference in prolactin (Sorensen et al. 1998). Furthermore, prolactin depletion has only a small effect on bovine milk yield (Knight, 2001), whereas in many other species it is the principal galactopoietic hormone (Flint \& Knight, 1997). Prolactin can affect food intake. Hyperphagic responses caused by lactation (in rats, Gerardo-Gettens et al. 1989) and by increasing daylength (in male reindeer (Rangifer tarandus tarandus), Ryg \& Jacobsen, 1982) can be mimicked by prolactin injection. However, prolactin administration to dairy cows had no effect on either milk yield or food intake (Plaut et al. 1987).

Oxytocin is the milk ejection hormone, produced in response to suckling and acting on myoepithelial cells to cause contraction of secretory alveoli, dilatation of ducts and hence expulsion of milk. It has no direct action on milk secretion per se (Knight, 1994), but since milk yield is sensitive to the efficiency of udder emptying (Wilde et al. 1989 ) it will have an indirect galactopoietic effect. Oxytocin is produced by neurones in the paraventricular and supraoptic nuclei of the hypothalamus, both areas that are implicated in the control of appetite (Williams et al. 2000). It has long been considered capable of exerting a central anorexic effect in rodents (Verbalis et al. 1995), and there is limited data to suggest it has the same effect in cows (Svennersten et al. 1990). The role of oxytocin is by no means clear-cut. For instance, one report describes a stimulation of appetite after central administration in rats (Bjorkstrand \& Uvnas-Moberg, 1996). It is not considered to be a major 
player in the same way as leptin or the recently discovered orexins (Williams et al. 2000). Nevertheless, it is the one hormone which could explain the anomaly in the Kibbutz cows; suckled cows had considerably higher oxytocin levels than the other two groups, and were the only cows to eat less than expected (Bar-Peled et al. 1995). The factor which is currently attracting most interest in relation to control of food intake is leptin. It is interesting, therefore, to note that a recent study has shown expression of leptin receptor on 'virtually all' oxytocin neurones in the supraoptic nucleus of the lactating rat hypothalamus (Brogan et al. 2000).

\section{Leptin}

Leptin is an endocrine product of adipose tissue, predicted several decades ago from parabiosis studies in obese (ob/ob) mice and positively identified in 1994 following the cloning of the $o b$ gene (Zang et al. 1994). Although expressed in several other tissues including, apparently, the mammary gland (Chilliard et al. 2000), its concentration is closely related to fat mass and it exerts an anorexigenic or appetitesuppressing action at the level of the hypothalamus. Hence, in an era when human obesity is increasing dramatically, leptin has attracted very considerable interest as a regulator of metabolism or, more fancifully, as the 'lean' hormone. Reviews of leptin are numerous (for example, see Harris, 2000; Spiegelman \& Flier, 2001) but are mainly clinically orientated. Many data exist for man and rodents, but little for ruminants due to the absence of reliable assays. This situation has been remedied recently with the introduction of specific ovine and bovine assays (Block et al. 2000; Delavaud et al. 2000; Thomas et al. 2001), and it is likely that within the next few years an abundance of data will appear concerned with leptin and dairy-cow energetics. Some interesting strands of information are already emerging, mainly in sheep. As expected, leptin correlates with body fatness and is lower during underfeeding (Delavaud et al. 2000). The effect of nutrition is particularly related to the energy content of the diet, and is greater in ewe lambs than ram lambs (Ehrhardt et al. 2000). The effects of pregnancy are less clear. There is evidence of increased leptin secretion in pregnant rodents (Chien et al. 1997), but a recent study failed to confirm this observation in sheep, although leptin was nutritionally regulated in much the same way as in non-pregnant animals (Thomas et al. 2001). Some of the sheep in this study were already catabolic well before parturition, and these animals had the lowest leptin values. It is tempting to speculate that the decreasing intake of the late-pregnant cow may be a consequence of increasing leptin. If so, one would then expect leptin to fall during lactation, in line with the increased intake. Recent measurements in sheep (A Sorensen, C Adams and RG Vernon, personal communication) show indeed that leptin is reduced from about $9 \mathrm{ng} / \mathrm{ml}$ to about $2 \mathrm{ng} / \mathrm{ml}$ during lactation, and a similar decrease is evident in cattle (Block et al. 2000). In a qualitative sense this decrease was predictable, but it occurs very soon after parturition, before fat has been mobilised and before food intake has increased, and there is then no further decrease during the period in which appetite gradually increases, so the two factors do not correlate. Experiments in lactating rats have produced a similar conclusion. Milk yield was varied by adjusting the number of suckling pups. This approach produced parallel changes in food intake, in the total absence of any change in leptin (R Denis and R G Vernon, personal communication). As more information emerges it becomes apparent that simple relationships between leptin concentration and intake do not exist; most obese human subjects have normal leptin concentrations. It is highly likely that leptin serves as a warning signal of too little fat rather than too much (Vernon, 2000), which for the mobilising cow could be a vital function. In an experiment where we forced lactating cows into extreme mobilisation we were able to demonstrate a fail-safe system which markedly and abruptly down regulated yield before the cow's health became compromised (Knight et al. 1999), but we could not identify what triggered this response; leptin, perhaps?

\section{Conundrums and explanations}

Declining food intake in late pregnancy is somewhat paradoxical in an animal which will need as many resources as possible to deal with the energetic demands of very high milk yield. It has been ascribed to sheer physical constraints imposed by the growing feto-placental unit, but this explanation is too simplistic. Late-pregnant cows fed highconcentrate diets show a greater depression than those on high-forage diets (Coppock et al. 1972); it is energy, not volume, which dictates intake. Food intake is negatively influenced by oestrogens, which increase during late pregnancy. Tempting as it is to ascribe a link between these observations, cause and effect has not been established (Ingvartsen et al. 1999). The critical experiments assessing food intake of late-pregnant cows of varying body composition have not been done; would a lean cow not show the prepartum decrease in intake? Probably not!

The bigger apparent conundrum is why intake lags behind output in early lactation, but if one restates the question, some obvious answers start to emerge. What advantages are conferred by relying on mobilisation rather than increased intake to fuel the first few weeks of lactation? The biggest threat to the wild ungulate is predation and, from this point of view, being fat is bad news. Having got fat whilst relying on the security provided by being part of a large herd, the more solitary lactating female will wish to lose weight rapidly for her own survival. Energetically, mobilisation confers approximately $80 \%$ efficiency, whilst digestion is only about $60 \%$ efficient, so at the time of greatest demand there is an energetic advantage (although the total energetic cost of depositing fat and then mobilising it is obviously much greater). There is less need for physical activity (foraging), and gut proliferation does not need to happen so rapidly, all of which confers more energetic efficiency. Perhaps the real conundrum is why so much effort is exerted by agricultural nutritionists and dairy famers in trying to persuade the early-lactation cow to eat more. She knows better!

\section{Flexibility to avoid extremes}

Much of the description up to this point has referred specifically to the first lactation cycle, but in considering flexibility 
it is important to think in lifetime terms about the factors that drive the mother to reproduce. Her objective is to maximise the chances of her genes surviving to the next generation and beyond, so the more young successfully reared the better. For an essentially monotocous species with a long gestation length, maternal investment theory (Trivers, 1974) predicts very considerable investment in lactation, as has been described. At some stage, however, the decision must be made to stop investing in the current offspring in order to start investing in the next one; in short, to rebreed. Most feral ungulates are highly seasonal. Reproductive activity is geared to the young being born in spring or early summer, such that peak lactation coincides with the greatest chance of abundant food. If young are to be reared successfully in consecutive seasons, it follows that the sum of gestation and lactation must be less than 12 months in duration, otherwise rebreeding must occur before the lactation has finished, such that lactation and gestation run concurrently. Quite obviously, the latter option will impose additional energetic costs on the mother, costs which cannot always be met in the wild. Muskoxen (Ovibos moschatus) have a gestation length (34 weeks) not dissimilar to cattle. They inhabit inhospitable arctic regions and exhibit highly seasonal breeding. The chances of a lactating muskox rebreeding are not high and are very dependent on body condition (Adamczewski et al. 1998). Similar conclusions have been drawn in red deer (Cervus elaphus); poor nutritional conditions result in rebreeding every second year, rather than every year (Loudon \& Kay, 1984). If rebreeding fails, the mother can still fulfill her teleological drive by continuing to lactate and so invest in the first youngster, and subjective observations indicate that those muskoxen which do not rebreed pursue exactly this option (PF Flood, personal communication).

The essence of successful domestication is to improve conditions for the farmed species in order to gain greatest benefit from the desired characteristic(s). This approach brings us back to the principles of intensive lactation. The farmer supplies quality food all year round, while the cow responds with plentiful milk and a calf each year. The effect of many generations of domestication on the animal's physiology is apparent from the almost total lack of seasonality in reproductive cycles; especially remarkable given that annual cyclicity is still apparent in such things as hoof horn growth (MacCallum, 1999). The evidence of reducing fertility (by which is meant inability to rebreed early in lactation; Webb et al. 1999) shows, however, that reproduction is still very much constrained by the same output-related energetic factors which prevent the lactating muskox from rebreeding. This constraint is a problem if the desired outcome is another calf, but the economic value of dairy-breed bull calves is minimal, and the advent of reproductive technologies such as sexed semen and multipleovulation embryo transfer means that a dedicated industry could quickly remove the need for the dairy farmer to generate his own replacement heifers. Perhaps the time is ripe to learn lessons from muskoxen, and to redirect our efforts into concentrating investment in the current offspring. In other words, having got the cow to the point of producing milk, persuade her to carry on doing so for as long as possible at a level which is metabolically, energetically and commercially sustainable. This strategy is based on extended lactation, and to achieve it one has to know more about the biological factors which control lactation persistency.

\section{Flexibility in lactation persistency}

The 'normal' lactation length for a mouse is about 3 weeks. However, feral mice are communal nesters and will frequently suckle multiple offspring. If this practice is mimicked experimentally by regularly swapping the ageing litter of pups for a younger litter, the lactation can be extended almost indefinitely (Bruce, 1958), with milk yield maintained at about two-thirds of its peak lactation value (Shipman et al. 1987). By stimulating the release of galactopoietic hormones (particularly prolactin; Flint et al. 1984) and by removing milk in order to prevent feedback inhibition, vigorous suckling can largely prevent the usual decline in milk yield. How plastic is lactation persistency in ruminants? Goats implanted with perphenazine in the hypothalamic median eminence exhibit elevated prolactin release, and there is evidence of increased lactation persistency as a result (Vandeputte-Van Messom \& Peeters, 1982). However, in a number of experiments using pharmacological and photoperiodic manipulations we have been unable to show similar effects (Brown, 1996; Alamer, 1998). McFadden (1997) reviewed bovine lactation persistency and identified factors such as better persistency of the heifer lactation, poorer persistency of higheryielding cows, effects of season and nutrition and poorer persistency in concurrently pregnant cows. All this information was derived from an analysis of national databases, since until very recently there has been no systematic investigation of persistency in a controlled experimental fashion. Recent attempts at modelling extended lactation have adopted the same approach (Vargas et al. 2000). The problem is that virtually all farmers attempt to rebreed for 12-month calving intervals, so cows presenting with longer lactations are, by and large, there by default; they are the ones which have failed to rebreed. In reality, what is being modelled is calving interval, not extended lactation, because no attempt has been made to deliberately extend the lactation. A recent analysis of high-yielding Israeli dairy cows deliberately rebred for calving intervals of 12 or 14 months (heifers) or 11.5 and 13 months (cows) revealed greater profitability from the longer lactations, despite there being no intervention to improve persistency (Arbel et al. 2001). The different targets for heifers and cows is interesting; presumably there was insufficient confidence to attempt 14-month lactations in older cows which would be expected to have poorer persistency. A recent Swedish study has compared cows managed for 12-, 15- and 18-month calving intervals. Reproduction data have been published (Ratnayake et al. 1998), but production data have not as yet, although an early report referred to longer dry periods in the 18-month cows, suggestive of a failure to improve persistency (Bertilsson et al. 1998). 

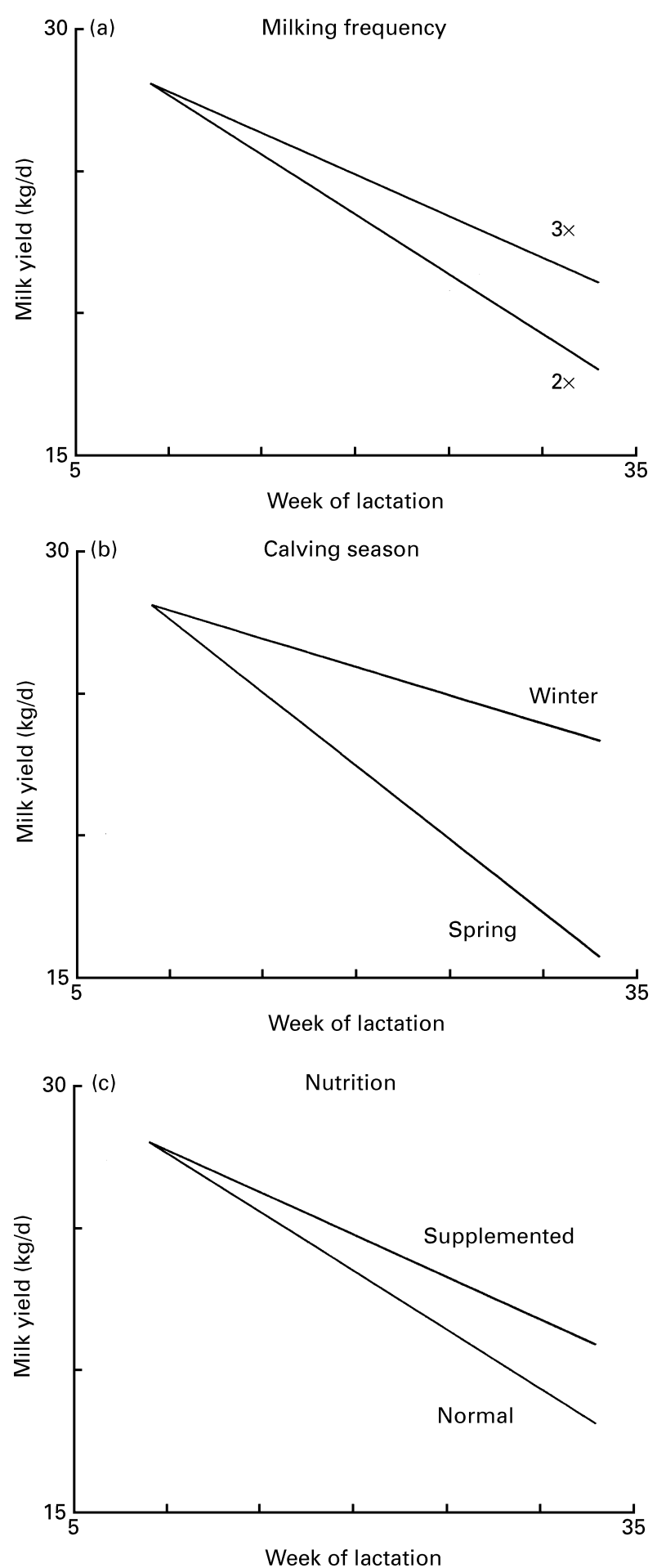

Fig. 2. Effects of (a) milking frequency, (b) calving season and (c) nutrition on lactation persistency in dairy cows. Treatments commenced in lactation week 9 and comprised three times daily $(3 \times)$ or two times daily $(2 \times)$ milking and additional concentrate supplement (supplemented) of $3 \mathrm{~kg} / \mathrm{d}$, with twelve cows per treatment group. For graphical presentation milk yield data were adjusted to a common start point and best-fit linear regression analysis was applied. Statistical evaluation was made of slopes fitted to actual data. (a) The difference between treatments was significant (ANOVA): $P=0.03$. (b) The difference between seasons was significant (ANOVA): $P<0.001$. (c) The difference between treatments was not significant (ANOVA): $P=0.07$. (From Sorensen \& Knight, 2000.)

\section{Control of lactation persistency}

Our own recent data (Sorensen, 2000) has also indicated a potential for better profitability from longer lactations. The approach was rather different, in that management was based around lactation performance rather than rebreeding time. We examined the effects of milking frequency, nutrition and calving season on lactation persistency (Sorensen \& Knight, 2000). The former treatments started at peak lactation, and Fig. 2 shows persistency slopes for the different treatments. It will be seen that persistency is plastic, and can be improved by milking more frequently, feeding more concentrate during declining lactation and by calving in the winter rather than the summer. We have previously observed a positive effect of milking frequency when applied together with $\mathrm{GH}$ in goats; indeed, in this case milk yield hardly declined at all during the 22 weeks of treatment (Knight et al. 1990). Measurement of mammary development and involution has shown that the reason milk yield declines after peak lactation is loss of secretory cells, rather than any decrease in the functionality of the cells that survive (Knight \& Wilde, 1987). Cell loss is by apoptosis (Wilde et al. 1997), which is controlled through a complex interaction between prolactin, GH, IGF-1 and IGF-binding protein-5 (Flint \& Knight, 1997). Briefly, IGF-1 is a survival factor for mammary cells, but sequestration by IGF-binding protein5 prevents this action. GH stimulates intramammary release of IGF-1 and prolactin prevents local secretion of IGF-binding protein-5, so that when both hormones are present cells survive, but if either of the hormones is absent cells die by apoptosis. This interaction almost certainly explains why the frequent milking and $\mathrm{GH}$ combination is so effective, because frequent milking not only stimulates prolactin release but also increases mammary sensitivity through prolactin receptor up regulation (Bennett et al. 1990). Significantly, although those American dairy farmers who are using recombinant $\mathrm{GH}$ to increase milk yield are still being advised to calve their cows every year, many are achieving extremely persistent lactations (Van Amburgh et al. 1997).

\section{Benefits of extended lactation}

The biggest beneficiary would be the cow herself, through reduced lifetime exposure to the peak risk period of parturition and early lactation. The average productive life of a modern dairy cow is only 3 years, during which time she will calve three times. Switching to 18 -month lactation cycles would mean only two calvings in the same period of time, a reduction of one-third in risk exposure. Since culling is heavily influenced by parity, it is probably the case that the cow on extended lactations would enjoy a longer life, and there would be less need for culling and replacement. This approach also means fewer calves being born, with a consequent reduction in unwanted bull calves. It is important to remember that the essence of extended lactation is continued production at a metabolically sustainable level, i.e. a cow working well within her capabilities and with ample time to replenish body reserves in readiness for future lactations. There are economic 
arguments in favour of extended lactation (Knight \& Mainland, 1995; Galligan \& Lormore, 2000), so the farmer would also benefit, and the milk retailing and processing industries would benefit from a more stable year-round supply of a more consistent product (Knight et al. 2000). For a more detailed account of the benefits, see Knight (1998).

\section{Conclusions}

The cow's investment in reproduction is considerable, the strategy employed being one of accretion of body reserves followed by intense mobilisation during the early stages of lactation and then increased intake initially to support the continued lactation and then to replenish reserves. By and large the long-term integration of intake and output is well regulated, as is short-term coordination, even if superficially it may appear otherwise. The period around parturition and early lactation is the most hazardous, and the feral ungulate will not take on this challenge (will not rebreed) if she is not equipped with sufficient body reserves to meet it. Instead, she will continue to lactate in order to invest in the current offspring. Extended lactation based on this principle could be an efficient and welfare-friendly alternative to intensive dairy production.

\section{References}

Adamczewski JZ, Fargey PJ, Laarveld B, Gunn A \& Flood PF (1998) The influence of fatness on the likelihood of early-winter pregnancy in muskoxen (Ovibos moschatus). Theriogenology 50, 605-614.

Akers RM (1985) Lactogenic hormones: binding sites, mammary growth, secretory cell differentiation and milk biosynthesis in ruminants. Journal of Dairy Science 68, 501-519.

Alamer M (1998) Manipulation of ruminant lactation using photoperiod and endocrine treatment. PhD Thesis, University of Glasgow.

Anil MH \& Forbes JM (1980) Feeding in sheep during intraportal infusions of short-chain fatty acids and the effect of liver denervation. Journal of Physiology 298, 407-414.

Anon (2000) Production and Management Symposium: Management of dairy herds for 40,000 pounds of milk per year. Journal of Dairy Science 83, Suppl. 1, 25-26.

Arbel R, Bigun Y, Ezra E, Sturman H \& Hojman D (2001) The effect of extended calving intervals in high-yielding lactating cows on milk production and profitability. Journal of Dairy Science 84, 600-608.

Bareille N \& Faverdin P (1996) Lipid metabolism and intake behaviour of dairy cows: effects of intravenous lipid and betaadrenergic supplementation. Journal of Dairy Science 79, 1209-1220.

Bar-Peled U, Aharoni Y, Robinzon B, Bruckental I, Lehrer R, Maltz E, Knight CH, Kali J, Folman Y, Voet H, Gacitua H \& Tagari H (1998) The effect of enhanced milk yield of dairy cows by frequent milking or suckling on intake and digestibility of the diet. Journal of Dairy Science 81, 1420-1427.

Bar-Peled U, Maltz E, Bruckental I, Folman Y, Kali Y, Gacitua H, Lehrer AR, Knight CH, Robinzon B, Voet H \& Tagari H (1995) Relationship between frequent milking or suckling in early lactation and milk production of high producing dairy cows. Journal of Dairy Science 78, 2726-2736.
Bauman DE (1992) Bovine somatotrophin: review of an emerging animal technology. Journal of Dairy Science $\mathbf{7 5}$, 3432-3451.

Bauman DE \& Currie WB (1980) Partitioning of nutrients during pregnancy and lactation: a review of mechanisms involving homeostasis and homeorhesis. Journal of Dairy Research 63, 1514-1529.

Bauman DE, Eppard PJ, De Geeter MJ \& Lanza GM (1985) Responses of high-producing dairy cows to long-term treatment with pituitary somatotropin and recombinant somatotropin. Journal of Dairy Science 68, 1352-1362.

Bauman DE, Everett RW, Weiland WH \& Collier RJ (1999) Production responses to bovine somatotrophin in Northeast dairy herds. Journal of Dairy Science 82, 2564-2573.

Beever DE, Cammell SB, Sutton JD, Rowe N \& Perrott GE (1998) Energy metabolism in high yielding dairy cows. Proceedings of the British Society of Animal Science 1998, p. 13. Pencuik, Midlothian: British Society of Animal Science.

Bell AW (1995) Regulation of organic nutrient metabolism during transition from late pregnancy to early lactation. Journal of Animal Science 73, 2804-2819.

Bell AW, Burhans WS \& Overton TR (2000) Protein nutrition in late pregnancy, maternal protein reserves and lactation performance in dairy cows. Proceedings of the Nutrition Society 59, 119-126.

Bennett CN, Knight CH \& Wilde CJ (1990) Regulation of mammary prolactin binding by secreted milk proteins. Journal of Endocrinology 127, Suppl., 141.

Bertilsson J, Berglund B, Osterman S, Rehn H \& Tengroth G (1998) Extended calving intervals - a way to optimise future milk production? 1. Effects on productivity. In Book of Abstracts of the 49th Annual Meeting of the European Association for Animal Production no. 170 [JAM van Arendonk, editor]. Warsaw, Poland: Wageningen Pers.

Bjorkstrand E \& Uvnas-Moberg K (1996) Central oxytocin increases food intake and daily weight gain in rats. Physiology and Behavior 59, 947-952.

Block SS, Butler WR, Ehrhardt RA, Bell AW \& Boisclair YR (2000) Effect of energy balance on the concentration of plasma leptin in early lactating dairy cows. Journal of Animal Science 78, Suppl. 1, 19.

Bray GA (2000) Afferent signals regulating food intake. Proceedings of the Nutrition Society 59, 373-384.

Brogan RS, Grove KL \& Smith MS (2000) Differential regulation of leptin receptor but not orexin in the hypothalamus of the lactating rat. Journal of Neuroendocrinology 12, 1077-1086.

Broster WH (1971) The effect on milk yield of the cow of the level of feeding before calving. Dairy Science Abstracts 33, 253-270.

Brown J (1996) Investigation of factors influencing lactation persistency in the goat. PhD Thesis, University of Glasgow.

Bruce HM (1958) Suckling stimulus and lactation. Proceedings of the Royal Society of London 149, 421-423.

Chalupa W \& Galligan DT (1989) Nutritional implications of somatotropin for dairy cows. Journal of Dairy Science 72, 2510-2524.

Chien EK, Hara M, Rouard M, Yano H, Phillippe M, Polonsky KS \& Bell GI (1997) Increase in serum leptin and uterine leptin receptor messenger RNA levels during pregnancy in rats. Biochemical and Biophysical Research Communications 237, 476-480.

Chilliard Y, Bonnet M, Delavaud C, Barb CR, Taouis M, Dridi S, Faulconnier Y, Bocquier F, Kann G \& Djiane J (2000) Leptin in farm animals: homologous assays in plasma and expression in body tissues. In Book of Abstracts of the 51st Annual Meeting of 
the European Association of Animal Production, p. 225 [JAM van Arendonk, editor]. The Hague, The Netherlands: Wagengingen Pers.

Coppock CE, Noller CH, Wolfe SA, Callahan CJ \& Baker JS (1972) Effect of forage-concentrate ratio in complete feeds fed ad-libitum on feed intake prepartum and the occurrence of abomasal displacement in dairy cows. Journal of Dairy Science 55, 783-789.

Delavaud C, Bocquier F, Chilliard Y, Keisler DH, Gertler A \& Kann G (2000) Plasma leptin determination in ruminants: effect of nutritional status and body fatness on plasma leptin concentration assessed by specific RIA in sheep. Journal of Endocrinology 165, 519-526.

Drackley JK (1999) Biology of dairy cows during the transition period: the final frontier? Journal of Dairy Science 82, 2259-2273.

Ehrhardt RA, Slepetis RM \& Bell AW (2000) Nutritional regulation of circulating leptin in growing lambs is influenced by sex. Journal of Dairy Science 83, Suppl. 1, 72-73.

Erb HN, Smith RD, Hillman RB, Powers PA, Smith MC, White ME \& Pearson EG (1984) Rates of diagnosis of six diseases of Holstein cows during 15-day and 21-day intervals. American Journal of Veterinary Research 45, 333-335.

Esslemont D \& Kossaibati A (2000) Dairy farming systems: husbandry, economics and recording. In The Health of Dairy Cattle, pp. 299-327 [AH Andrews, editor]. Oxford: Blackwell Science.

Farm Animal Welfare Council (1997) Report on the Welfare of Dairy Cattle. London: MAFF.

Flint DJ, Clegg RA \& Knight CH (1984) Effects of prolactin, progesterone and ovariectomy on metabolic activities and insulin receptors in the mammary gland and adipose tissue during extended lactation in the rat. Journal of Endocrinology 102, 231-236.

Flint DJ \& Knight CH (1997) Interactions of prolactin and growth hormone $(\mathrm{GH})$ in the regulation of mammary gland function and epithelial cell survival. Journal of Mammary Gland Biology and Neoplasia 2, 41-48.

Galligan D \& Lormore L (2000) Economics of atypical milk production. Journal of Dairy Science 83, Suppl. 1, 24.

Gerardo-Gettens T, Moore BJ, Stern JS \& Horwitz BA (1989) Prolactin stimulates food intake in a dose-dependent manner. American Journal of Physiology 256, R276-R280.

Gibb MJ, Ivings WE, Dhanoa MS \& Sutton JD (1992) Changes in body components of autumn-calving Holstein-Friesian cows over the first 29 weeks of lactation. Animal Production 55, 339-360.

Grohn Y, Saloniemi H \& Syvajarvi J (1986) An epidemiological and genetic study on registered diseases in Finnish Ayrshire cattle: I. The data, disease occurrence and culling. Acta Veterinaria Scandinavica 27, 182-195.

Harris RBS (2000) Leptin - much more than a satiety signal. Annual Review of Nutrition 20, 45-75.

Ingvartsen KL \& Andersen JB (2000) Integration of metabolism and intake regulation: a review focusing on periparturient animals. Journal of Dairy Science 83, 1573-1597.

Ingvartsen KL, Andersen HR \& Foldager J (1992) Effect of sex and pregnancy on feed intake capacity of growing cattle. Acta Agriculturae Scandinavica 42, 40-46.

Ingvartsen KL, Friggens NC \& Faverdin P (1999) Food intake regulation in late pregnancy and early lactation. British Society of Animal Science Occasional Publication no. 24, pp. 37-54. Pencuik, Midlothian: British Society of Animal Science.

Johnson WL, Trimberger GW, Wright MJ, Van Vleck LD \& Henderson CR (1966) Voluntary intake of forage by Holstein cows as influenced by lactation, gestation, body weight and frequency of calving. Journal of Dairy Science 49, 856-864.
Knight CH (1994) Short-term oxytocin treatment increases bovine milk yield by enhancing milk removal without any direct action on mammary metabolism. Journal of Endocrinology 142, 471-473.

Knight CH (1998) Extended lactation. Hannah Research Institute Yearbook 1998, pp. 30-39. Ayr: Hannah Research Institute.

Knight CH (2001) Overview of prolactin's role in farm animal lactation. Livestock Production Science 70, 87-93.

Knight CH, Beever DE \& Sorensen A (1999) Metabolic loads to be expected from different genotypes under different systems. British Society of Animal Science Occasional Publication no. 24, pp. 27-35. Pencuik, Midlothian: British Society of Animal Science.

Knight CH, Fowler PA \& Wilde CJ (1990) Galactopoietic and mammogenic effects of long-term treatment with bovine growth hormone and thrice daily milking in goats. Journal of Endocrinology 127, 129-138.

Knight CH \& Mainland D (1995) Physiology of milk production; how can it be manipulated. Cattle Practice 3, 169-173.

Knight CH, Sorensen A \& Muir D (2000) Non-nutritional (novel) techniques for manipulation of milk composition. British Society of Animal Science Occasional Publication no. 25, 223-239. Pencuik, Midlothian: British Society of Animal Science.

Knight CH \& Wilde CJ (1987) Mammary growth during lactation: implications for increasing milk yield. Journal of Dairy Science 70, 1991-2000.

Koprowski JA \& Tucker HA (1973) Serum prolactin during various physiological states and its relationship to milk production in the bovine. Endocrinology 92, 1480-1487.

Kossaibati MA \& Esslemont RJ (2000) The incidence of lameness in 50 dairy herds in England. In Proceedings of the XI International Symposium on Disorders of the Ruminant Digit, pp. 160-162 [CM Mortellaro, L DeVecchis and A Brizzi, editors]. Parma, Italy: Fondazione Iniziative Zooprofilattiche e Zootecniche.

Loudon ASI \& Kay RNB (1984) Lactational constraints on a seasonally breeding mammal: the red deer. Symposia of the Zoological Society of London 51, 233-252.

MacCallum AJ (1999) A cell biological approach to studying lameness in the dairy cow. PhD Thesis, Glasgow University.

McFadden TB (1997) Prospects for improving lactation persistency. In Milk Composition, Production and Biotechnology, pp. 319-339 [RAS Welch, DJW Burns, SR Davis, AI Popay and GC Prosser, editors]. Wallingford, Oxon.: CAB International.

Morrison SD (1956) The total energy and water metabolism during pregnancy in the rat. Journal of Physiology 134, 650-664.

Oftedal OT (2000) Use of maternal reserves as a lactation strategy in large mammals. Proceedings of the Nutrition Society 59, 99-106.

Plaut K, Bauman DE, Agergaard N \& Akers RM (1987) Effect of exogenous prolactin administration on lactational performance of dairy cows. Domestic Animal Endocrinology 4, 279-290.

Pond CM (1984) Physiological and ecological importance of energy storage in the evolution of lactation: Evidence for a common pattern of anatomical organization of adipose tissue in mammals. Symposia of the Zoological Society of London 51, $1-32$.

Pryce JE, Veerkamp RF, Thompson R, Hill WG \& Simm G (1997) Genetic aspects of common health disorders and measures of fertility in Holstein Friesian dairy cattle. Animal Science 65, $353-360$.

Ratnayake DRTG, Berglund B, Bertilsson J, Forsberg M \& Gustafsson H (1998) Fertility in cows managed for calving intervals of 12, 15 or 18 months. Acta Veterinaria Scandinavica 39, 215-228. 
Robinson JJ (1986) Changes in body composition during pregnancy and lactation. Proceedings of the Nutrition Society $\mathbf{4 5}$, $71-80$.

Roseler DK, Fox DG, Chase LE, Pell AN \& Stone WC (1997) Development and evaluation of equations for prediction of feed intake for lactating Holstein dairy cows. Journal of Dairy Science 80, 878-893.

Ryg M \& Jacobsen E (1982) Effects of thyroid hormones and prolactin on food intake and weight changes in young male reindeer (Rangifer tarandus tarandus). Canadian Journal of Zoology $\mathbf{6 0}$, $1562-1567$.

Shipman LJ, Docherty AH, Knight CH \& Wilde CJ (1987) Metabolic adaptations in mouse mammary gland during a normal lactation cycle and in extended lactation. Quarterly Journal of Experimental Physiology 72, 303-311.

Sinowatz F, Schams D, Kolle S, Plath A, Lincoln D \& Waters MJ (2000) Cellular localisation of GH receptor in the bovine mammary gland during mammogenesis, lactation and involution. Journal of Endocrinology 166, 503-510.

Sorensen A (2000) Manipulation of lactation persistency to achieve extended lactation in dairy cows. $\mathrm{PhD}$ Thesis, University of Glasgow.

Sorensen A, Alamer M \& Knight CH (1998) Physiological characteristics of high genetic merit and low genetic merit dairy cows: a comparison. Proceedings of the British Society of Animal Science 1998, p. 4. Pencuik, Midlothian: British Society of Animal Science.

Sorensen A \& Knight CH (2000) Effect of milking frequency, nutrition and calving season on lactation persistency. In Book of Abstracts of the 51st Annual Meeting of the European Association for Animal Production, p. 219 [JAM van Arendonk, editor]. The Hague, The Netherlands: Wageningen Pers.

Spiegelman BM \& Flier JS (2001) Obesity and the regulation of energy balance. Cell 104, 531-543.

Svennersten K, Nelson L \& Uvnas-Moberg K (1990) Feedinginduced oxytocin release in dairy cows. Acta Physiologica Scandinavica 140, 295-296.

Thomas L, Wallace JM, Aitken RP, Mercer JG, Trayhurn P \& Hoggard N (2001) Circulating leptin during ovine pregnancy in relation to maternal nutrition, body composition and pregnancy outcome. Journal of Endocrinology 169, 465-476.

Trivers RL (1974) Parent-offspring conflict. American Zoologist 14, 249-264.

Tucker HA (2000) Hormones, mammary growth and lactation; a 41-year perspective. Journal of Dairy Science 83, 874-884.
Van Amburgh M, Galton D, Bauman D \& Everett RW (1997) Management and economics of extended calving intervals with use of BST. Livestock Production Science 50, 15-28.

Vandeputte-Van Messom G \& Peeters G (1982) Effect of hypothalamic implantation of perphenazine on milk yield of goats. Journal of Endocrinology 94, 267-270.

Vargas B, Koops WJ, Herrero S \& Van Arendonk JAM (2000) Modeling extended lactations of dairy cows. Journal of Dairy Science 83, 1371-1380.

Veerkamp RF, Simm G \& Oldham JD (1995) Genotype by environment interactions: experience from Langhill. British Society of Animal Science Occasional Publication no. 19, pp. 59-66. Pencuik, Midlothian: British Society of Animal Science.

Verbalis JG, Blackburn RE, Hoffman GE \& Stricker EM (1995) Establishing behavioural and physiological functions of central oxytocin: insights from studies of oxytocin and ingestive behaviours. Advances in Experimental Medicine and Biology 395, 209-225.

Vernon RG (2000) Signals of adiposity. In Book of Abstracts of the 51st Annual Meeting of the European Association of Animal Production, p. 225 [JAM van Arenctonk, editor]. The Hague, The Netherlands: Wagengingen Pers.

Vernon RG, Clegg RA \& Flint DJ (1981) Metabolism of sheep adipose tissue during pregnancy and lactation. Biochemical Journal 200, 307-314.

Vernon RG \& Pond CM (1997) Adaptations of maternal adipose tissue to lactation. Journal of Mammary Gland Biology and Neoplasia 2, 231-241.

Webb R, Garnsworthy P, Gong JG, Robinson RS \& Wathes DC (1999) Consequences for reproductive function of metabolic adaptation to load. British Society of Animal Science Occasional Publication no. 24, pp. 99-112. Pencuik, Midlothian: British Society of Animal Science.

Wilde CJ, Addey CVP, Li P \& Fernig DG (1997) Programmed cell death in bovine mammary tissue during lactation and involution. Experimental Physiology 82, 943-953.

Wilde CJ, Blatchford DR, Knight CH \& Peaker M (1989) Metabolic adaptations in goat mammary tissue during long-term incomplete milking. Journal of Dairy Research 56, 7-15.

Williams G, Harrold JA \& Cutler DJ (2000) The hypothalamus and the regulation of energy homeostasis: lifting the lid on a black box. Proceedings of the Nutrition Society 59, 385-396.

Zang Y, Proenca R, Maffei M, Barone M, Leopold L \& Friedman JM (1994) Positional cloning of the mouse obese gene and its human homologue. Nature 372, 425-432. 